УДК 330:338

DOI: https://doi.org/10.54929/pmt-issue2-2021-3

\title{
УПРАВЛІННЯ ІННОВАЦІЙНО-ІНВЕСТИЦІЙНИМ РОЗВИТКОМ ПІДПРИЄМНИЦТВА В УМОВАХ ТРАНСФОРМАЦІЙНОЇ ЕКОНОМІКИ
}

\author{
MANAGEMENT OF INNOVATIVE AND INVESTMENT DEVELOPMENT \\ OF ENTREPRENEURSHIP IN TRANSFORMATION ECONOMY \\ CONDITIONS
}

\author{
Косач I. A. \\ доктор економічних наук, професор, \\ профессор кафедри публічного управління \\ та менеджменту організацій, \\ Національний університет «Чернігівська політехніка» \\ ORCID ID: 0000-0003-1730-7140 \\ Дегтярьов А. В. \\ аспірант кафредри публічного управління \\ та менеджменту організацій, \\ Національний університет «Чернігівська політехніка» \\ ORCID ID: 0000-0003-2665-2544 \\ Iryna Kosach \\ Doctor of Economics, Professor, \\ Professor of Department of Public Administration \\ and Organizations' Management, \\ National university «Chernigiv polytechnics»
}

Artem Degtiarov
Candidate of Phd,
Department of Public Administration
and Organizations' Management,
National university «Chernigiv polytechnics»

Досліджено основні напрямки та пріоритети управління інноваційно-інвестиційним розвитком підприємництва в умовах трансформаційних процесів в економіці України. Розглянуто ключові принципи державної підтримки підприємництва на прикладі підприємств малого бізнесу. Обгрунтовано важливість інноваційно-інвестиційного розвиткупідприємниитва, зокрема малого бізнесу, для вітчизняноїекономіки. Проведено аналіз інвестиційної активності підприємств малого та середнього бізнесу. Проаналізовано стан виконання Стратегії розвитку малого та середнього підприємництва до 2020 р. та досліджено ії вплив на інноваційно-інвестиційнудіяльність субєктів господарювання. Класифріковано фактори, якіперешкоджаютьінноваційно-інвестиційномурозвиткумалих та середніхпідприємств. Обгрунтованопередумови формування результативної економічної підтримки з боку держави в напрямку інноваційно-інвестиційного розвитку підприємництва. Ключові слова: державне регулювання, інвестиції, інновації, малий бізнес, підприємництво.

Исследованы основные направления и приоритеты управления инновационно-инвестиционным развитием предпринимательства в условиях трансформационных процессов в экономике Украины. Рассмотрены ключевые принципы государственной поддержки предпринимательства на примере малого бизнеса. Обоснована важность инновационно-инвестиционного развития малого предпринимательства для отечественной экономики. Проведен анализ инвестиционной активности предприятий малого и среднего бизнеса. Проанализировано состояние выполнения Стратегии развития малого и среднего предпринимательства до 2020 е. и исследовано ее влияние на инновационно-инвестиционную деятельность субъектов хозяйствования. Классифицированы фракторы, препятствующие инновационно-инвестиционному развитию предприятий малого бизнеса. Обоснованы предпосылки фоормирования результативной экономической поддержки со стороны государства в направлении инновационно-инвестиционного развития сектора малого предпринимательства. Ключевые слова: государственное регулирование, инвестиции, инновации, малый бизнес, предпринимательство.

It is noted that the main motivating factor for economic growth of business entities is innovation and investment development, which is based on new advanced technologies, management approaches, involves the development of high-tech products. The aim is to study the management of innovation and investment development of entre- 
preneurship in the context of transformational change. Research methodology is a set of principles, approaches, general theoretical, special, and interdisciplinary methods of scientific knowledge, namely morphological analysis, comparative analysis, methods of deduction and logical generalization, analysis and synthesis. The main directions and priorities of management of innovation and investment development of small business in the conditions of transformation processes in the economy of Ukraine are investigated. The key principles of state support of small business are considered. The importance of innovation and investment development of small business for the domestic economy is substantiated. The analysis of investment activity of small and medium business enterprises is carried out. The state of implementation of the Strategy for the Development of Small and Medium-sized Enterprises until 2020 is analyzed and its impact on the innovation and investment activities of economic entities is studied. Factors that hinder the innovation and investment development of small and medium enterprises are classified. Prerequisites for the formation of effective economic support from the state in the direction of innovation and investment development of the small and medium enterprise sector are substantiated. It is proposed that the entrepreneurship sector should be segmented not by quantitative parameters, which include the number of employees, gross income and statutory fund, but by qualitative criteria. It is noted that the result of the state policy of supporting the innovation and investment development of small and medium enterprises depends on the effective work of government. Key words: government regulation, investment, innovation, small business, entrepreneurship.

Постановка проблеми. В умовах інтеграції України до європейського співтовариства, модернізації системи державної економічної політики з орієнтацією на європейські стандарти для зміцнення конкурентоспроможності на ринку та ефективної інноваційної діяльності підприємницькі структури шукають нові інвестиційні можливості, освоюють нові підходи до інвестування. Проте головним мотивуючим фактором економічного зростання суб'єктів підприємництва залишається інноваційно-інвестиційний розвиток, який ґрунтується на нових прогресивних технологіях, управлінських підходах, передбачає освоєння випуску високотехнологічної продукції. Отже, особливості сучасної економічної ситуації в Україні на тлі безлічі внутрішніх проблем і зовнішніх загроз, в тому числі апливу пандемії COVID -19, підвищують значимість інноваційно-інвестиційного розвитку підприємництва, зокрема, малого бізнесу як пріоритетної сфрери економіки.

Аналіз останніх досліджень і публікацій. 3'ясуванню сутності підприємництва як одного із важливих чинників соціально-економічного розвитку країни світова наука приділяє значну увагу. Багатоаспектність досліджуваної проблеми, розвиток напрямів державної підтримки малих підприємств набули свого висвітлення в напрацюваннях таких вчених, як А. Бутенко, М. Войнаренко, 3. Варналій, Л. Донець, Б. Купчак, В. Ляшенко, Н. Романенко, Д. Стеченко, К. Шапошников та інших. При цьому вважаємо за доцільне зазначити, що трансформаційні процеси в економіці потребують поглиблення існуючих підходів щодо процесів управління інноваційно-інвестиційним розвитком підприємництва в контексті державної економічної політики.

Формулювання цілей статті (постановка завдання). Метою статті $€$ дослідження управління інноваційно-інвестиційним розвитком підприємництва в умовах трансформаційних змін.

Виклад основного матеріалу дослідження. Підприємництво $є$ важливою складовою економіки країни, мобільною і гнучкою до змін ринкового середовища, що уможливлює визнавати його підґрунтям фрормування умов економічного зростання. Особливу роль при цьому відіграють підприємства малого та середнього бізнесу Етимологічно термін «малий бізнес» в Україні має походження із англомовної літератури, в якій застосовується визначення «small business». Саме в такому варіанті він і використовується до теперішнього часу, від простого усного вживання до законодавчих та нормативно-правових актів щодо цього сектора економіки. Використання термінології «суб'єкти малого підприємництва» і «суб'єкти середнього підприємництва» здійснюється у відповідності із Законом України «Про розвиток та державну підтримку малого і середнього підприємництва в Україні» у значенні, наведеному в Господарському кодексі України, з урахуванням того, що в цілях цього Закону термін «суб'єкти малого підприємництва» охоплює суб'єктів мікропідприємництва [5].

За даними Світового банку, загальна кількість показників, за якими підприємство належить до суб'єктів малого підприємництва, перевищує 50. Частіше всього з цією метою використовується показник чисельності персоналу. Так, в Україні до суб'єктів малого підприємництва відносяться підприємства, де середня чисельність працівників за звітний період не перевищує:

1) у промисловості - 100 чол.;

2) у будівництві, на транспорті - 100 чол.;

3) у сільському господарстві - 60 чол.;

4) у науково-технічній сфрері - 100 чол.;

5) в оптовій торгівлі - 50 чол.;

6) у дрібній торгівлі та побутовому обслуговуванні населення - 30 чол.;

7) в інших галузях та видах діяльності-50 чол.

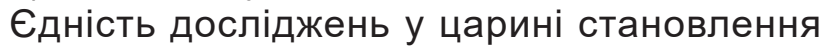
та розвитку малого бізнесу полягає у визначенні його ролі в господарському механізмі, при цьому підприємець визначається як провідна фрігура соціально - економічних відносин. Наприклад, здійснення підприємницької діяльності на засадах інноваційності відзначає дослідник Б. Купчак, розглядаючи підприємництво з точки зору відно- 
син, що формуються з приводу «виробництва, розподілу та привласнення благ і послуг на основі комбінування підприємцем фракторів виробництва та відповідальності за власні рішення «вкладеними коштами, затратами часу і праці, діловою репутацією й своїм майбутнім прибутком» [4, с. 247]. Отже, підприємницька ініціатива, новаторство і ризик присутні в якості взаємопов'язаних елементів підприємницької діяльності, тільки ступінь прояву кожного елемента в різний час проявляється по-різному в залежності від умов здійснення підприємництва.

Переважаючим залишається твердження, що головними цілями і мотивами підприємця $є$ зростання капіталу, розвиток виробництва і привласнення прибутку. Підтвердженням цьому виступає і тлумачення сутності підприємництва у нормативно-правових документах. На наш погляд, таке твердження $є$ недостатньо актуальним, враховуючи умови сьогодення. В умовах трансформаційних процесів взаємодія відносин власності, процес отримання прибутку та сутність підприємницької діяльності слід розглядати, на нашу думку, із врахуванням принципу динамічного розвитку. В умовах інформаційно-інноваційної революції право власності на засоби виробництва не виступає домінуючою характеристикою підприємницької діяльності, проте значення набуває право інтелектуальної власності.

Як зазначають в своєму дослідженні К. Шапошников та О. Головко, у сучасних економічних умовах державне регулювання та підтримка малого бізнесу в Україні $\epsilon$ важливою передумовою його активізації у подоланні кризових явищ та забезпеченні економічного розвитку [9, с. 237].

В законі України «Про розвиток та державну підтримку малого та середнього підприємництва» визначено ключові принципи надання державної підтримки. До них віднесено:

1) ефективність підтримки малого і середнього підприємництва;

2) доступність отримання державної підтримки суб'єктами малого і середнього підприємництва;

3) забезпечення участі представників суб'єктів малого і середнього підприємництва, громадських організацій у формуванні та реалізації державної політики в зазначеній сорері;

4) створення рівних можливостей для доступу суб'єктів малого і середнього підприємництва, що відповідають вимогам, передбаченим загальнодержавними, регіональними та місцевими програмами розвитку малого і середнього підприємництва, до участі у виконанні таких програм та для отримання державної підтримки;

5) ефективність використання бюджетних коштів, передбачених для виконання зазначених програм;

6) відкритість і прозорість проведення процедур надання державної підтримки;

7) доступність об'єктів інфрраструктури підтримки малого і середнього підприємництва для всіх суб'єктів малого і середнього підприємництва [5].

Державна підтримка полягає у наданні фрінансової, майнової, інфоормаційної та консультаційної підтримки підприємствам малого і середнього бізнесу в країні. Також, надається допомога в підготовці, підвищенні кваліфікації, перепідготовки працівників, здійснюється підтримка в області інновацій, ремісництва, промислового виробництва, підтримка підприємців, що займаються сільськогосподарською та зовнішньоекономічною діяльністю.

Фінансова підтримка малому і середньому підприємництву здійснюється відповідно до чинного законодавства України за рахунок використання коштів державного бюджету і коштів місцевих бюджетів. Вона реалізується шляхом надання бюджетних інвестицій, субсидій, державних і муніципальних гарантій за зобов'язаннями малого і середнього бізнесу.

Важливість розвитку малого підприємництва для вітчизняної економіки та необхідність активізації державної економічної політики в напрямку його підтримки доводить аналіз діяльності малого і середнього підприємництва в Україні за 2018-2019 pp., який дозволив виявити, що 99,98\% юридичних осіб та фрізичних осіб - підприємців (ФОП), зареєстрованих в Україні, належать до суб'єктів малого і середнього підприємництва. Частка зайнятих в секторі малого та середнього підприємництва склала 82\% або 6,9 млн. осіб. На сектор припадає 65\% обсягу реалізації товарів, робіт та послуг та 64\% валової доданої вартості [6].

Проте, як показують проведені дослідження, негативним фрактором впливу на розвиток малого та середнього підприємництва виступає низький рівень інноваційності. В Україні як на макрорівні, та і регіональному та місцевому рівнях, відсутні сприятливі умови виконання підприємствами малого та середнього бізнесу ролі інноваційної компоненти розвитку національної економіки. Метою регулювання інноваційного розвитку сектора малого та середнього підприємництва має стати зростання інноваційної активності, а це є можливим лише за умови максимального використання інвестиційного потенціалу сектора із врахуванням його регіональних особливостей. Як правило, зазначена негативна тенденція викликана недостатнім рівнем фрінансування, хоча, якщо аналізувати обсяги кредитування зазначеного сектору, на середні, малі та мікропідприємства припадає понад половина обсягів кредитування, що на 01.01.2020 становило 431 млрд. грн. Це приблизно дорівнює частці зазначених суб'єктів господарювання в українському ВВП, що відображено у Звіті про державну підтримку підприємств малого та се- 
реднього бізнесу [6].

Аналіз інвестиційної активності підприємств малого та середнього бізнесу та динаміки інвестицій, наведений на рис. 1, дає змогу зробити висновок про ії̈ значну перевагу у сфері охорони здоров'я та надання соціальної допомоги, а також у сільському, лісовому та рибному господарстві. Інвестиції мають, як правило, поточний характер, i, з огляду на специфіку зазначених галузей, не пов'язані із розробкою нових технологій або продуктів.

У 2018 р. була прийнята Стратегія розвитку малого та середнього підприємництва до 2020 р. та для ії забезпечення створений Офріс розвитку малого та середнього підприємництва. Стратегія передбачала реалізацію 35 завдань за наступними напрямами:

- створення сприятливого середовища для розвитку малого і середнього підприємництва;

- покращення доступу малого та середнього підприємництва до фрінансування;

- спрощення податкового адміністрування;

- популяризацію підприємницької культури та розвиток підприємницьких навичок;

- підсилення конкурентоспроможності та інноваційного потенціалу;

- організаційне забезпечення та механізм реалізації Стратегії [8].

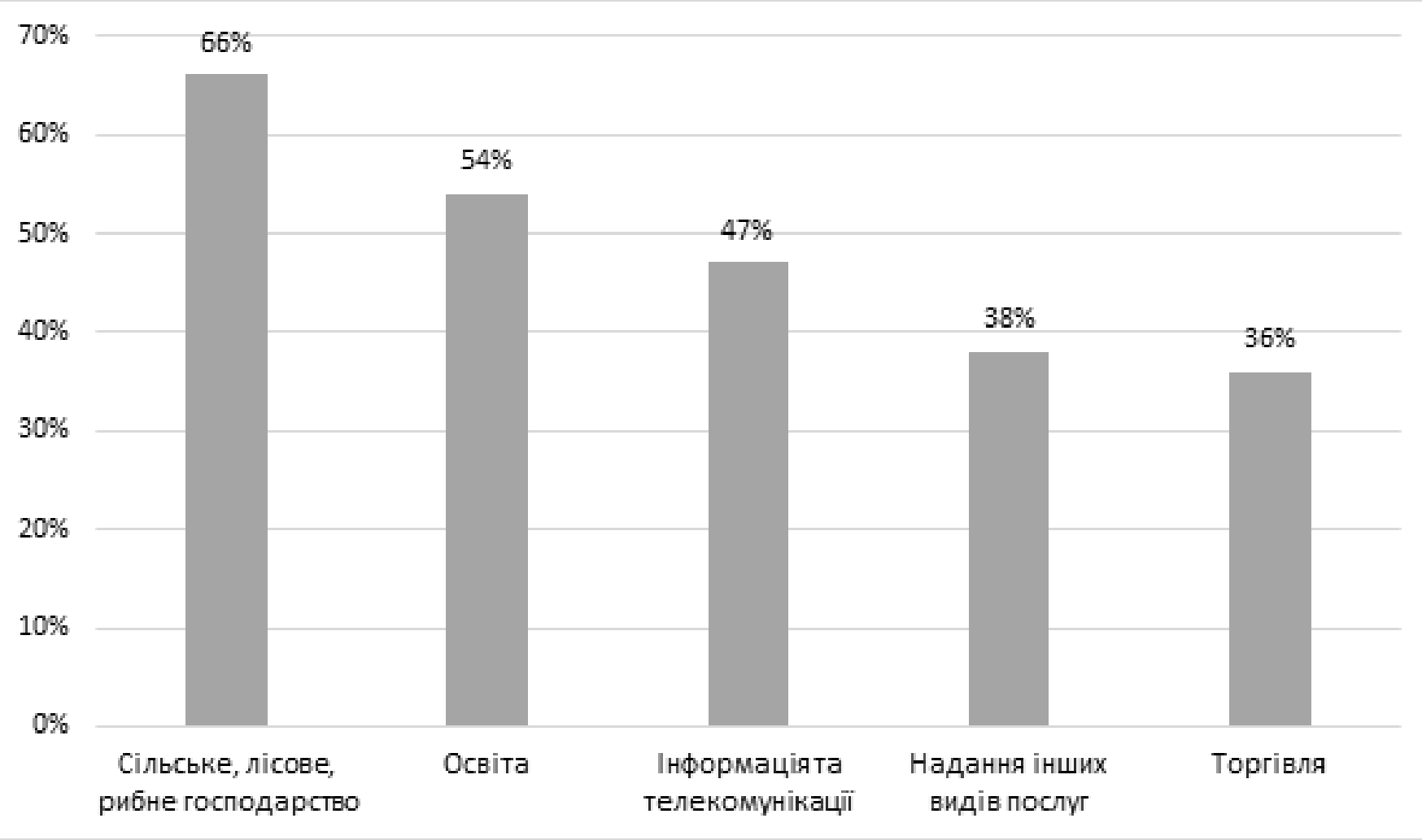

Рис. 1. Інвестиційна діяльність підприємств малого та середнього бізнесу за сорерами діяльності

Джерело: складено автором за даними Державного комітету статистики України

За кожним напрямом був сорормований план заходів, стан виконання яких свідчить про те, що із 63 передбачених заходів повністю був забезпечений напрямок «Підсилення конкурентоспроможності та інноваційного потенціалу» та «Популяризація підприємницької культури та розвиток підприємницьких навичок». Найбільш проблемними для реалізації виявились напрямки, що стосувались функціонування фінансового механізму розвитку. Дійсно, на початок 2020 року кредити малого бізнесу становили $56,1 \%$ від загального кредитного порторелю корпоративного сектору, з них середні $-24,7 \%$, малі-9,8\%, мікро-21,7\%, в той же час кредити надані великим інтегрова- ним структурам склали 79,1\% [6]. Конкретизація виконання Стратегії відображена на рис. 2.

Стан розвитку малого підприємництва та його інноваційно-інвестиційної складової дозволив класифікувати фрактори, які перешкоджають інноваційно-інвестиційному розвитку малих та середніх підприємств, наступним чином (рис. 3).

Для формування результативної економічної підтримки з боку держави в напрямку інноваційноінвестиційного розвитку сектора малого та середнього підприємництва необхідною $є$ наявність наступних передумов:

1. Організаційні передумови. Сектор підприємництва має бути сегментований не за кількісними параметрами, до яких відноситься кількість 
Створення сприятливого середовища для роввитку

Покращення доступу до фінансування

Спрощення податкового апміністрування

Популяризапія підприемнищької культури та розвиток навичок

Підсилення конкурентоспроможності та інноваційного потенціалу

Opганізапійне забезпечення і механізм реалізапіі crparerii

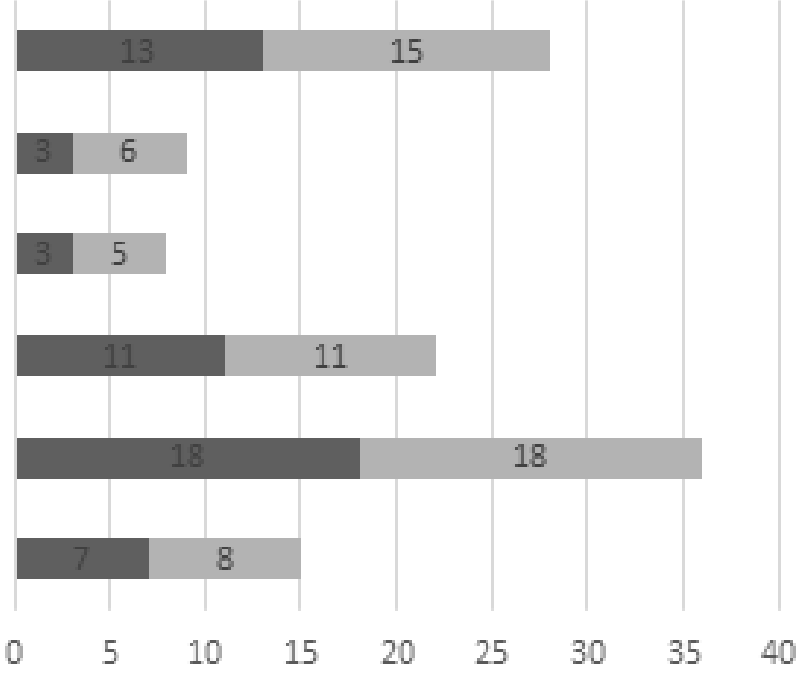

Факт п План

Рис. 2. Стан виконання Стратегії розвитку малого та середнього підприємництва до 2020 р. Джерело: сформовано автором за [8]

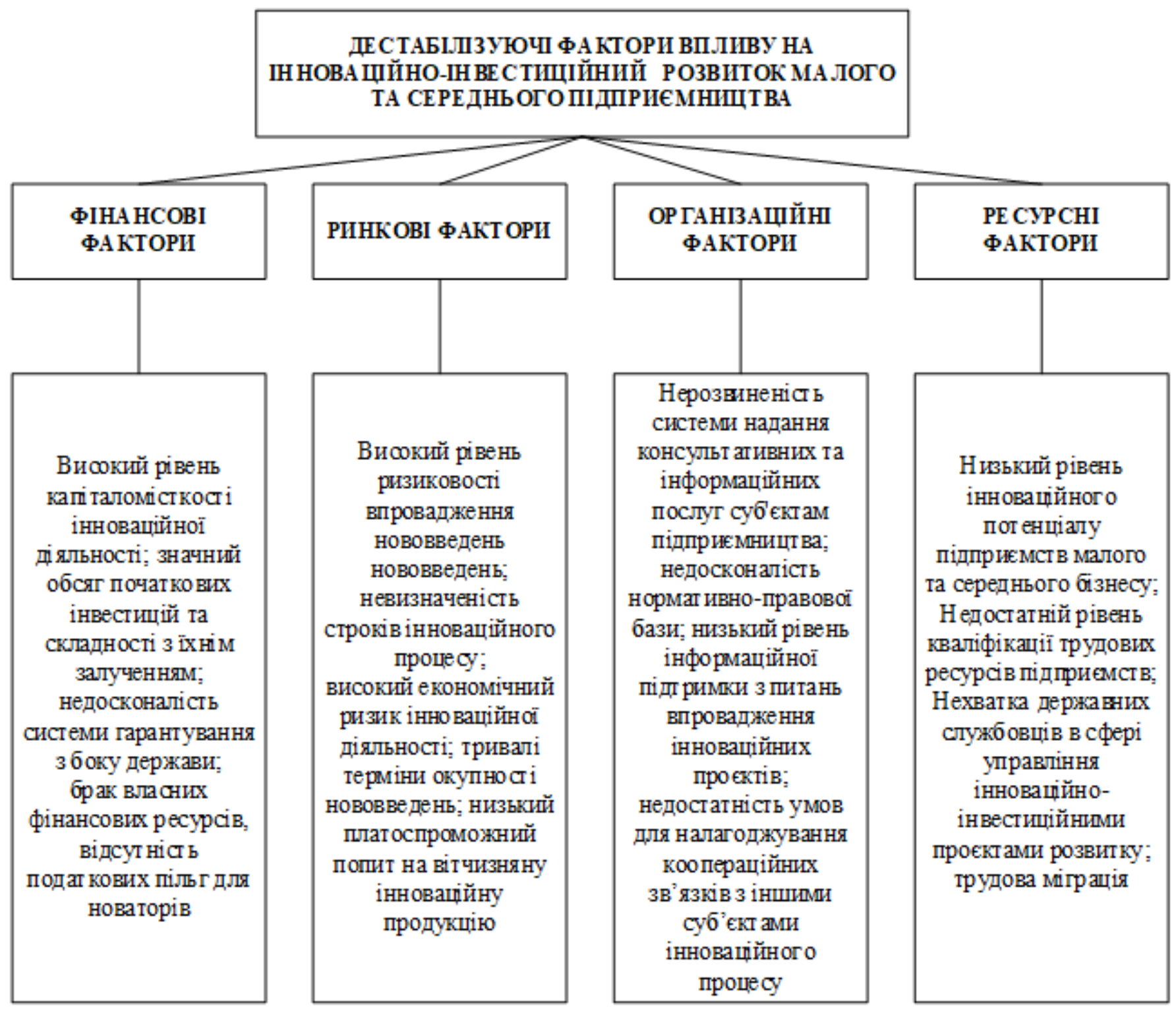

Рис. 3. Система фракторів впливу на інноваційно-інвестиційний розвиток малого та середнього підприємництва

Джерело: розроблено автором 
найманих працівників, розмір валового доходу та статутного фонду, а за якісними критеріями. Це потребує закріплення на законодавчому рівні диференціації суб'єктів малого та середнього підприємництва за рівнями господарської зрілості та наявним інноваційним потенціалом з метою підсилення адресності інструментів державної економічної політики. В залежності від відповідності критеріям можуть бути застосовані як інструменти адміністративного регулювання, так і фінансові інструменти, оскільки кожна фоокус-група суб'єктів малого та середнього підприємництва вимагає особливих форм, методів та інструментів механізму реалізації державної політики.

2. Економічні передумови. Результат державної політики підтримки інноваційно-інвестиційного розвитку малого та середнього підприємництва залежить від ефективної роботи органів влади, що в свою чергу грунтується на раціональному співвідношенні ресурсів, стимулів та повноважень. При цьому доцільно врахувати взаємозв'язок між ресурсами та стимулюванням, оскільки достатня кількість ресурсів вже виступає стимулюючим фрактором розвитку. Мають бути враховані не лише ресурси суб'єкта підприємництва, а і ресурсний потенціал органів державної влади в контексті можливості забезпечення фінансового, консультативного та інформаційного супроводу інноваційноінвестиційних проєктів. Ідея стимулювання також може бути реалізована шляхом надання стимулюючих дотацій як регіону із державного бюджету, так і окремим муніципальним утворенням з бюджету області за результатами проведеного моніторингу інноваційно-інвестиційного розвитку підприємництва та інноваційно-інвестиційного потенціалу.

3.Інституційні передумови. Для підсилення взаємозв'язку між рівнями державної політики інноваційно-інвестиційного розвитку підприємни- цтва, враховуючи пріоритети реформи децентралізації влади, необхідним є запровадження засад і принципів стратегічного управління. Акцент має бути зроблений також на підтримку інноваційної інфраструктури, формування кластерів індустріальних парків, бізнес-інкубаторів і т.ін.

Досвід розвитку малого та середнього бізнесу в країнах ЄС показує, що важливою умовою успіху є підтримка держави, яка можлива у різних формах, наприклад, шляхом стимулювання виробництва стратегічних видів продукції, надання податкових канікул, доступного банківського кредитування, створення інформаційноконсультативних центрів, адаптивної системи страхування.

Висновки. Управління інноваційно-інвестиційним розвитком підприємництва, зокрема, малого та середнього бізнесу, потребує заходів державної підтримки, яка має створити умови для використання ключових функцій підприємництва з метою забезпечення сталого розвитку національної економіки, зокрема для досягнення таких цілей, як зайнятість, формування раціональної структури виробництва, розвиток окремих секторів економіки, підвищення податкових надходжень до бюджету, підвищення добробуту, збільшення доходів на душу населення, зростання ВВП, активізація інновацій в економіці. Пріоритетним аспектом також має бути сприяння фрормуванню середнього класу як запоруки стійкості соціальних відносин та політичної стабільності. Крім цього, управління інноваційно-інвестиційним розвитком малого та середнього бізнесу повинно ґрунтуватися на аналізі підприємницького середовища і забезпечуватися ефрективністю роботи організацій інфраструктури підтримки.

\section{БІБЛІОГРАФІЧНИЙ СПИСОК:}

1. Бутенко А., Войнаренко М., Ляшенко В. Модернізація механізмів розвитку малого та середнього бізнесу: монографрія: НАН України, Ін-т економіки пром-сті. Донецьк, 2011. 326 с.

2. Варналій 3. С. Основи підприємництва: навч. посіб. К.: Знання-Прес, 2006. 350 с.

3. Донець Л.І., Романенко Н.Г. Основи підприємництва: навчальний посібник. Київ : Центр навчальної літератури, 2006. 320 с.

4. Купчак Б. Ф. Підприємництво: суть та умови здійснення. Науковий вісник НЛтУ України. 2011. Вип. 21.2. C. 243-249.

5. Про розвиток та державну підтримку малого і середнього підприємництва в Україні: Закон України від 22.03.2012 № 4618-VI. 170. URL: http://zakon2.rada.gov.ua/laws/ show/4618-17 (дата звернення 20.11.2021).

6. Статистичний щорічник України за 2019 рік. Київ : Державний комітет статистики України, 2020.568 с.

7. Стеченко Д.М. Стратегічне управління знаннями в інноваційній діяльності корпоративних утворень. Теоретичні та прикладні питання економіки. 2014. Вип. 1. С. 60-69.

8. Стратегія розвитку малого і середнього підприємництва в Україні на період до 2020 p. URL:https://www. oecd.org/global-relations/SMEPI-EaP-2020-Ukraine.pdf (дата звернення 19.11.2021).

9. Shaposhnykov K., Holovko O. Public regulation and administration in the sphere of small business. Baltic Journal of Economic Studies. Vol. 5. 2019. No 4. September. Pp. 236 - 242. https://doi.org/10.30525/2256-0742/2019-5-4236-242 


\section{REFERENCES:}

1. Butenko, A., Voinarenko, M., \& Liashenko, V. (2011) Modernizaciya mekhanizmiv rozvitku malogo ta seredn'ogo biznesu [Modernization of mechanisms for small and medium business development]. Donetzk. (in Ukrainian).

2. Varnalij, Z. S. (2006). Osnovi pidpriyemnictva [Basics of business], Znannia-Pres, Kyiv, Ukraine (in Ukrainian).

3. Donets, L.I., Romanenko, N.G. (2006). Osnovi pidpriyemnictva [Basics of business]. Tsentr navchalnoi literatury. Kyiv. Ukraine (in Ukrainian).

4. Kupchak, B.F. (2011). Pidpryiemnytstvo: sut ta umovy zdiisnennia [Entrepreneurship: the essence and conditions of implementation]. Naukovyi visnyk NLTU Ukrainy - Scientific Bulletin of NLTU of Ukraine. Vol.21.2. 243249. (in Ukrainian).

5. The Verkhovna Rada of Ukraine (2012). The Law of Ukraine "On development and state support of small and medium business in Ukraine". (in Ukrainian). Available at: http://zakon2.rada.gov.ua/laws/ show/4618-17 (Accessed 20 Jul 2021).

6. Statystychnyi shchorichnyk Ukrainy za 2019 rik [Statistical Yearbook of Ukraine for 2019]. Derzhavnyi komitet statystyky Ukrainy. 2020. 568 (in Ukrainian).

7. Stechenko, D.M. (2014). Stratehichne upravlinnia znanniamy v innovatsiinii diialnosti korporatyvnykh utvoren [Strategic knowledge management in the innovative activities of corporate entities]. Teoretychni ta prykladni pytannia ekonomiky - Theoretical and applied issues of economics. Vol.1. 60-69. (in Ukrainian).

8. Stratehiia rozvytku maloho i serednoho pidpryiemnytstva v Ukraini na period do $2020 \mathrm{r}$. [Strategy for the development of small and medium enterprises in Ukraine until 2020]. (in Ukrainian). URL: https://www.oecd.org/ global-relations/SMEPI-EaP-2020-Ukraine.pdf (Accessed 19 Nov 2021).

9. Shaposhnykov, K., \& Holovko, O. (2019). Public regulation and administration in the sphere of small business. Baltic Journal of Economic Studies, 5(4), 236-242. https://doi.org/10.30525/2256-0742/2019-5-4-236-242 